\section{Fair and equitable conservation: do we really want it, and if so, do we know how to achieve it?}

The Convention on Biological Diversity (which will celebrate its 25th anniversary of ratification when this issue is published) requires conservation to be "fair and equitable" (CBD 2000). This proposition seems almost universally accepted, yet we see a gap between rhetoric and reality. In our experience, the notion of equity is still contested in Malagasy conservation, with certain questions recurring frequently. Here we present our own answers to those questions.

\section{WHAT SHOULD 'FAIR AND EQUITABLE' MEAN?}

We believe that for conservation to be fair and equitable, local people (who in Madagascar are almost exclusively among the world's very poorest) should bear no net negative impacts from conservation. It follows that they must be compensated for any residual costs of protected areas and other interventions, including opportunity costs. Ideally, this should be achieved by capturing global benefits and transferring them to local people. Conservation should not exacerbate poverty.

\section{DOES EQUITY IMPLY COMPENSATION?}

Fifteen years after Balmford \& Whitten (2003) argued that the global benefits of conservation generally come at local costs, Bedelian and Woodhouse (2018) identified the assertion that conservation is necessarily a win-win (because local people depend on ecosystem services) as their top "myth" in protected area management. In our experience, this myth remains prevalent in conservation discourse in Madagascar, despite numerous studies estimating net local costs of conservation (e.g., Shyamsundar and Kramer 1996, 1997, Kremen et al. 2000, Poudyal et al. 2018, see also Scales 2014, Neudert et al. 2017, though note that Rasolofoson et al. (2017) found no impacts, positive or negative, of community forest management). This evidence cannot be dismissed by pointing to hydrological or climatic benefits (which are frequently overstated: Bruijnzeel 2004, also Zwartendijk et al. 2017) or asserting that benefits from swidden agriculture are short-lived (they are not: Rakotonarivo et al. 2017, Poudyal et al. 2018). Nor can we assume that conservation is preventing a tragedy of the commons that would have impoverished local people, since it is difficult to disentangle traditional management from more than a century of state conservation action (and state-endorsed deforestation). Traditional tenure arrangements have evolved in re- sponse to state intervention (Muttenzer 2006), and any tragedy of the commons could have resulted from state conservation crowding out traditional norms (Rabesahala Horning 2003). In sum, while many knowledge gaps remain in Malagasy conservation, we need to shift to a default expectation that local people will bear costs of conservation that are significant in local terms, over long timescales, unless proven otherwise.

\section{IS COMPENSATION LEGITIMATE?}

Even when the prevalence of local costs is accepted, some question the legitimacy of compensation, noting that opportunity costs often result from the cessation of activities (e.g., swidden agriculture of primary forests) that are already illegal. Although internally consistent, it is inconsistent with the proposition that local people should not bear costs of conservation. The laws that prohibit deforestation are conservation laws, which have been reinforced and re-legitimised through the actions of the international conservation community (Kull 2004, Corson 2016, 2017). In particular, protected areas cannot claim additionality of avoided deforestation (e.g., for carbon credits or biodiversity offsets) while disclaiming the negative social impacts that result (Bidaud et al. 2018).

\section{IS COMPENSATION AFFORDABLE?}

some who accept the legitimacy of compensation doubt its affordability. We think the evidence is strong that conserving Madagascar's rich ecosystems has global and national benefits that vastly outweigh (in monetary terms) its local costs (e.g., Kremen et al. 2000, Hockley 2008, Poudyal et al. 2018). If we did not believe this was the case, we could not support conservation in Madagascar (could anyone justify a policy that was both inequitable and inefficient?). Capturing these global benefits is challenging, but this should not provide an excuse for not compensating local people: conservation should not facilitate 'free-riding' by the already wealthy. Conditionality is an increasingly popular concept in conservation discourse: that any payments for ecosystem services must be conditional on their provision. We simply argue for symmetry: provision of ecosystem services by the poorest should surely be conditional on their compensation.

\section{DO WE KNOW HOW TO ACHIEVE FAIR AND EQUI- TABLE CONSERVATION?}

If we agree that compensation for local costs is necessary, legitimate and affordable, do we know how to achieve it? As a result of discussing this question with government officials, conservation organisations and people who live around protected areas we have identified a number of challenges. Each of these is the focus of considerable efforts in Madagascar and elsewhere, but all remain substantially unresolved in our opinion.

ESTIMATING COSTS. As noted above, we have sufficient information from several Malagasy protected areas to conclude that local costs are likely to be significant and widespread. Nevertheless, these estimates are conceptually challenging, and contingent on many (often implicit) factors (Hockley 2008). The best available methods appear to perform quite well (e.g., Rakotonarivo et al. 2017), but given the timescales involved they are 


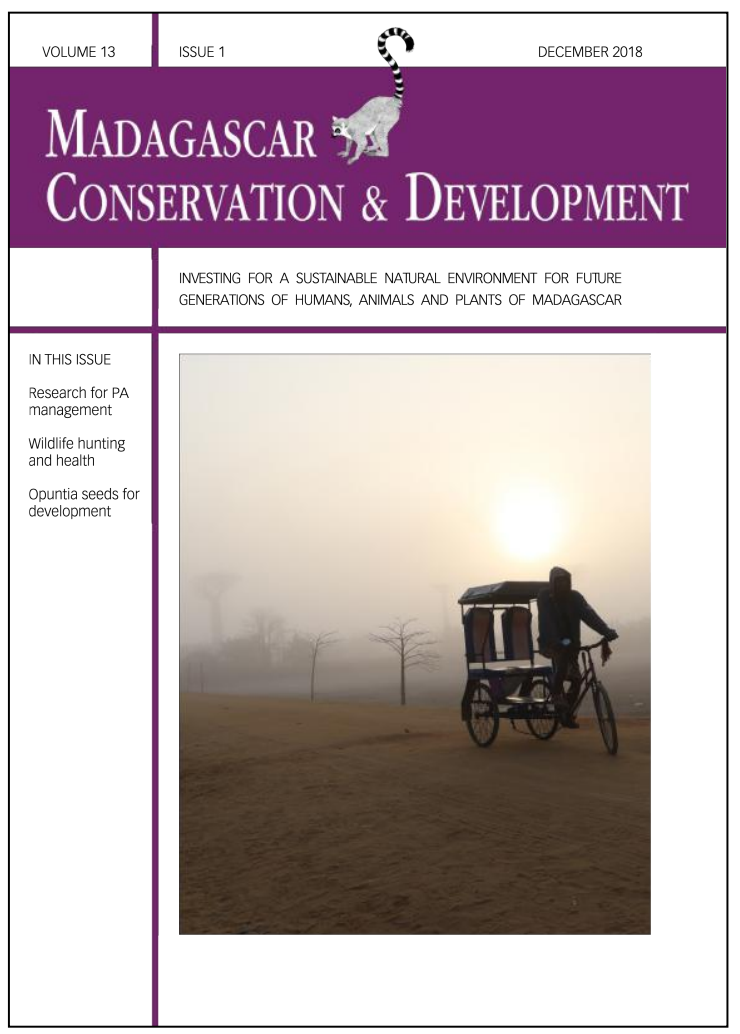

Madagascar Conservation \& Development is the journal of Indian Ocean e-Ink. It is produced under the responsibility of this institution. The views expressed in contributions to MCD are solely those of the authors and not those of the journal editors or the publisher.

All the Issues and articles are freely available at http://www.journalmcd.com

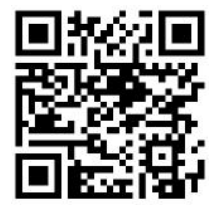

Contact Journal MCD

info@journalmcd.net for general inquiries regarding MCD funding@journalmcd.net to support the journal

Madagascar Conservation \& Development Institute and Museum of Anthropology

University of Zurich

Winterthurerstrasse 190

$\mathrm{CH}-8057$ Zurich

Switzerland

Indian Ocean e-Ink

Promoting African Publishing and Education

www.ioeink.com

Missouri Botanical Garden (MBG)

Madagascar Research and Conservation Program

Missouri Botanical Garden

BP 3391

Antananarivo, 101, Madagascar 
difficult to verify and robust tests remain the exception (Rakotonarivo et al. 2016). The distribution of costs over time and within households (across genders) remains an area deserving of more attention, as does qualitative evidence. Finally, all available methods can under- or overestimate costs when used to inform compensation for illegal or sensitive activities, if respondents understate sensitive behaviours (for fear of sanctions) or overstate (to inflate compensation).

COMPENSATION MECHANISMS. Estimates of opportunity costs are necessary but not sufficient to ensure adequate compensation. We need to know how much needs to be spent, for how long, and on what, to compensate for given costs, while allowing for transaction costs (Poudyal et al. 2016, 2018, Brimont et al. 2017, Mackinnon et al. 2017). Yet cost-effective mechanisms to reliably raise rural residents' wellbeing remain elusive. We suspect that most compensatory interventions are designed to fit within available budgets, not achieve compensation targets. At best, this is not discouraged by donors, and conservation NGOS may feel pressured to understate the true costs of achieving effective and equitable conservation. Donors who wish to support (and claim credit for) conservation in Madagascar need to demand evidence-based compensation plans, and recognise that donor commitments measured in years rather than decades are not commitments.

TARGETING COMPENSATION. The question of who should be targeted for compensation is thorny. Approaches that seek to avoid compensating individuals who have not borne costs are likely to have high implementation costs and be vulnerable to elite capture (Poudyal et al. 2016). Broader-scale compensation that seeks instead to minimise uncompensated individuals (while potentially over-compensating some) may be more efficient and equitable. Even then, if costs (and therefore compensations) wil occur over multiple generations, how should newly formed households be treated (along with immigration and emigration)?

EVALUATION AND OVERSIGHT. How do we know if what we are doing is working? Randomised Controlled Trials cannot be used to assess real compensatory interventions (where no eligible households should be excluded from compensation). Yet without them, it is difficult to be sure that compensation is succeeding. It might be useful to adopt pragmatic rules that approximate compensation, e.g., that incomes must rise, and must rise at least as fast as surrounding populations (though income growth in comparator communities may be negative). However, we should still invest in evaluations of compensation interventions that are as rigorous and independent as possible (e.g., Andrianandrasana 2016, Poudyal et al. 2018). Relatedly, how should fair and equitable compensation be monitored? At present, oversight tends to be top-down, and empirically weak. Mechanisms by which local communities can raise grievances are frequently absent or at best ad hoc, often mediated by conservation organisations, who therefore play judge and jury. The rights of local communities are poorly defined and understood. Current legal and administrative standards may not ensure adequate compensation (or seek to), and state enforcement capacity remains inadequate. Civil society in Madagascar is as yet inadequately developed to defend the interests of often remote rural communities.

\section{IS IT TIME FOR A RADICAL RETHINK?}

Two of us have argued elsewhere (Rakotonarivo and Hockley 2017) that one approach, which could alleviate some of the above problems, is to radically rethink tenure and consent in Madagascar's threatened habitats. Secure private (but not necessarily individual) tenure would be highly valued by communities (Rakotonarivo et al. 2018). Combined with voluntary conservation easements it would have several attractive characteristics. Free Prior Informed Consent is impossible without freedom of action (are communities free to refuse conservation?), and individuals, choosing freely, are probably the best judge of the worth of compensatory interventions. Committing to symmetrical conditionality might provide useful checks and balances on conservation and build local communities with a real stake in protecting natural capital against outsiders. However, such a radical approach is not without its own challenges. To name just a few: how to decide who owns forests? How would communities consent to, or reject, conservation collectively? Critically, the legal framework for this approach is absent in Madagascar (Jones et al. 2018) though this does not stop conservation organisations from acting, and pledging to act, as if it existed. Without secure local tenure of ecosystems, consent and compensation become much harder to ensure. It is therefore even more important to establish robust, independent oversight of the social impacts of conservation. Donors should demand (and fund) this oversight, and refuse to fund conservation activities that do not budget realistically for compensation. Without these changes, we are not optimistic about achieving fair and equitable conservation in Madagascar.

\section{ACKNOWLEDGMENTS}

$\mathrm{NH}$ and RM were supported by a Darwin Initiative Scoping Award (DARSC176) and OSR is supported by a European Research Council H2020/ERC grant no. 679651. We thank all those who have engaged in constructive discussions with us on these issues, and Julia Jones, Lucienne Wilmé and Patrick O. Waeber who made helpful comments on a draft of this editorial.

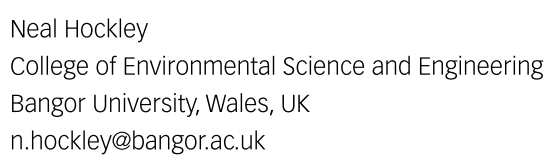

Rina Mandimbiniaina

Rainforest Trust

Rina@rainforesttrust.org

O. Sarobidy Rakotonarivo

Biological and Environmental Sciences

University of Stirling, Scotland, UK

sarobidy.rakotonarivo@stir.ac.uk 


\section{REFERENCES}

Andrianandrasana, H. 2016. Testing the effectiveness of community-based conservation in conserving biodiversity, protecting ecosystem services, and improving human well-being in Madagascar. Unpubl. Ph.D. thesis, University of Oxford. <https://goo.gl/qoMNXW>

Balmford, A. and Whitten, T. 2003. Who should pay for tropical conservation, and how could the costs be met. Oryx 37, 2: 238-250. <https://doi.org/10.1017/\$0030605303000413>

Bedelian, C. and Woodhouse, E. 2018. Challenging common myths in protected area management. ESPA Policy and Practice Briefing. $<$ https://goo.gl/X1YFoN>

Bidaud, C., Schreckenberg, K. and Jones, J. P. G. 2018. The local costs of biodiversity offsets: Comparing standards, policy and practice. Land Use Policy 77 : 43-50. <https://doi.org/10.1016/j.landusepol.2018.05.003>

Brimont, L., Ezzine-de-Blas, D. \& Karsenty, A. 2017. The cost of making compensation payments to local forest populations in a REDD+ pilot project in Madagascar. Madagascar Conservation \& Development 12, 1: 25-33. <https://doi.org/10.4314/mcd.v12i1.3>

Bruijnzeel, L. A. 2004. Hydrological functions of tropical forests: not seeing the soil for the trees? Agriculture, Ecosystems and Environment 104, 1: 185-228. <https://doi.org/10.1016/j.agee.2004.01.015>

CBD (Convention on Biological Diversity). 2000. COP 5 Decision V/6 <https://www.cbd.int/decision/cop/default.shtml?id=7148/>

Corson, C. A. 2016. Corridors of Power: The Politics of Environmental Aid to Madagascar. Yale University Press, New Haven.

Corson, C. 2017. A history of conservation politics in Madagascar. Madagascar Conservation \& Development 12, 1: 49-60. <https://doi.org/10.4314/mcd.v12i1.4>

Hockley, N. 2008. Cost Benefit Analysis for Global Environmental Issues. Ph.D., University of Wales. <http://e.bangor.ac.uk/4437/>

Jones, J. P. G., Mandimbiniaina, R., Kelly, R., Ranjatson, P., Rakotojoelina, B., et al. 2018. Human migration to the forest frontier: implications for land use change and conservation management. Geo: Geography and Environment 5, 1: e00050. <https://doi.org/10.1002/ge02.50>

Kremen, C., Niles, J. O., Dalton, M. G., Daily, G. C., Ehrlich, P. R., et al. 2000. Economic incentives for rain forest conservation across scales. Science 288 1828-1832. <https://doi.org/10.1126/science.288.5472.1828>

Kull, C. A. 2004. Isle of Fire. The Political Ecology of Landscape Burning in Madagascar. The University of Chicago Press, Chicago.

Mackinnon, J., Andriamaro, L., Rambeloson, A., Razafindrazakasoa, M. and Harvey, C. 2018. Costs of delivery approaches for providing livelihood projects to local communities as part of REDD+ programmes: An analysis from Madagascar. Environmental Conservation 45, 4: 324-332. <https://doi.org/10.1017/S0376892917000571>

Muttenzer, F. 2006. Déforestation et droit coutumier à Madagascar. L'Historicité d'une Politique Foncière. Université de Genève, Genève. <http://www.unige.ch/cyberdocuments/theses2006/MuttenzerF/these.pdf>

Neudert, R., Ganzhorn, J. U. and Wätzold, F. 2017. Global benefits and local costs The dilemma of tropical forest conservation: A review of the situation in Madagascar. Environmental Conservation 44, 1: 82-96. <https://doi.org/10.1017/S0376892916000552>

Poudyal, M., Ramamonjisoa, B. S., Hockley, N., Rakotonarivo, O. S., Gibbons, J. M., et al. 2016. Can REDD+ social safeguards reach the 'right' people? Lessons from Madagascar. Global Environmental Change-Human and Policy Dimensions 37: 31-42. <https://doi.org/10.1016/j.gloenvcha.2016.01.004>

Poudyal, M., Jones, J. P. G., Rakotonarivo, O. S., Hockley, N., Gibbons, J. M., et al. 2018. Who bears the cost of forest conservation? PeerJ 6: e5106. <https://doi.org/10.7717/peerj.5106>

Rabesahala Horning, N. 2003. How rules affect conservation outcomes. In: The Natural History of Madagascar. S. M. Goodman and J. P. Benstead (eds.), pp 146-153. The University of Chicago Press, Chicago.

Rakotonarivo, O. S. and Hockley, N. 2017. Forest conservation approaches must recognise the rights of local people. The Conversation. $<$ https://goo.gl/CiEvDU>
Rakotonarivo, O. S., Schaafsma, M. and Hockley, N. 2016. A systematic review of the reliability and validity of discrete choice experiments in valuing nonmarket environmental goods. Journal of Environmental Management 183, 1 : 98-109. <https://doi.org/10.1016/j.jenvman.2016.08.032>

Rakotonarivo, O. S., Jacobsen, J. B., Larsen, H. O., Jones, J. P. G., Nielsen, M. R., et al. 2017. Qualitative and quantitative evidence on the true local welfare costs of forest conservation in Madagascar: Are discrete choice experiments a valid ex ante tool? World Development 94: 478-491. <https://doi.org/10.1016/j.worlddev.2017.02.009>

Rakotonarivo, O. S., Jacobsen, J. B., Poudyal, M., Rasoamanana, A. and Hockley, N. 2018. Estimating welfare impacts where property rights are contested: methodological and policy implications. Land Use Policy 70: 71-83. $<$ https://doi.org/10.1016/j.landusepol.2017.09.051>

Rasolofoson, R. A., Ferraro, P. J., Ruta, G., Rasamoelina, M. S., Randriankolona, P.L., et al. 2017. Impacts of community forest management on human economic well-being across Madagascar. Conservation Letters 10, 3: 346-353. <https://doi.org/10.1111/conl.12272>

Scales, I. R. 2014. The future of conservation and development in Madagascar: time for a new paradigm? Madagascar Conservation \& Development 9, 1: 5-12. <https://doi.org/10.4314/mcd.v9i1.2>

Shyamsundar, P. and Kramer, R. A. 1996. Tropical forest protection: An empirical analysis of the costs borne by local people. Journal of Environmental Economics and Management 31, 2: 129-144. <https://doi.org/10.1006/jeem.1996.0036>

Shyamsundar, P. and Kramer, R. 1997. Biodiversity conservation - at what cost? A study of households in the vicinity of Madagascar's Mantadia National Park. Ambio 26, 3: 180-184.

Zwartendijk, B. W., van Meerveld, H. J., Ghimire, C. P., Bruijnzeel, L. A., Ravelona, M. and Jones, J. P. G. 2017. Rebuilding soil hydrological functioning after swidden agriculture in eastern Madagascar. Agriculture Ecosystems \& Environment 239: 101-111. <https://doi.org/10.1016/j.agee.2017.01.002> 